\title{
Nova Planta Japonica (I)
}

\author{
Auctore Masaji HondA
}

\section{本田正次：日本の新植物}

\section{Smilax sadoensis Honda sp. nov.}

Planta herbacea, erecta, $30-60 \mathrm{~cm}$ alta, simplex vel ramosa, robustiuscula, glabra. Caulis angulatus, striatulus. Folia alterna, petiolata, petiolis $0.7-20 \mathrm{~mm}$ longis basi vaginantibus margine undulatis, laminis ellipticis vel ovato-ellipticis, apice acutis vel acuminatis, basi cuneatis vel truncatulis, $8-10 \mathrm{~cm}$ longis, $3.5-6.5 \mathrm{~cm}$ latis, 5 -nervatis reticulatis, rugulosis, margine undulatis, supra glabris, nitidulis, subtus ad nervis saepe strigulosis. Stipulae cirrhatae. Flores axillares longe pedunculati, pedunculis 4-6 cm longis, umbellati, umbella 7-15-flora, glomerata. Flos $\delta:$ perianthium reflexum; stamina 6; epistillatus. Flos 우: perianthium reflexum; estaminatus.

Nom. Jap. Sado-shiode (nov.)

Hab.

Honshū: Ōnogame, ins. Sado (M. HondA, anno 1949-typus in Herb. Tokyo Univ.)

Near Smilax higoensis Miquel, but differs from this by its more robust stem, contracted internodes, multi-fold leaves, massed umbel, etc.

Sedum Shimizuanum Honda sp. nov.

Planta saxicola, glaberrima. Caulis erectus, $25-30 \mathrm{~cm}$ altus, teres, gracilis, praeter inflorescentia simplex, superior bulbillifer in autumno, inferior saepe rufescens. Folia ad nodum terna, subsessilia, oblonga, apice acutiuscula, $25-3 \mathrm{~cm}$ longa, 7-12 mm lata, succosa, margine dentata. Inflorescentia corymbosa, laxa, pauciflora. Flos parvus. Sepala oblongo-lanceolata, acuta, $1 \mathrm{~mm}$ longa, viridissima. Petala coarctata, oblonga, acuta, navicularia, 2.5-3 mm longa, viridia, margine scariosa. Stamina petala aequilonga. Anthera elliptica, $0.75 \mathrm{~mm}$ longa, leve sulphurea. Ovaria 5, liberta, viridia.

Nom. Jap. Chichibu-benkei (nov.)

Hab.

Honshū: in monte Ogura, prov. Shinano (D. SHImizu, anno 1950-typus in Herb. Tokyo Univ.)

Distinct from Sedum verticillatum LinnaEus by its half-opened flower, tufty stem and bulblets on stem in autumn.

Gentiana minor NAKAI var. minima HondA var. nov.

Planta humilis, 3-6 cm alta. Caulis solitarius. Folia minora, 4-5 $\mathrm{mm}$ longa. 
Nom. Jap. Ko-tateyamarindō (nov.)

$\mathrm{Hab}$.

Honshū : Mie, Prov. Ise (N. YAsul, no. 2, anno 1950-typus in Herb. Tokyo Univ.)

Hovenia dulcis Thunberg form. deviata.Honda form. nov.

Planta nana. Folia minora, 4-6 cm longa, 2-3 cm lata, aurata, tenuissima.

Nom. Jap. Ōgon.kenponashi (nov.)

Hab.

Honshū: Wakayanagi, prov. Rikuchū (M. HondA, anno 1945-typus in Herb. Tokyo Univ.)

Ligustrum japonicum Thunberg var. leucocarpa Honda var. nov.

Fructus albus vel flavescens.

Nom. Jap. Shiro-nezumimochi (nov.)

Hab.

Shikoku: Kōchi, prov. Tosa (T. Yamawaki, anno 1951-typus in Herb. Tokyo Univ.) var. repens HONDA var. nov.

Caulis repens, radicans.

Nom. Jap. Hai-nezumimochi (T. YamawaKI)

Hab.

Shikoku: in medio Yura-peninsulae, prov. Iyo (T. YAMAWAKI, anno 1951-typus in Herb. Tokyo Univ.)

Tilia japonica SimonkaI var. stenoglossa Honda var. nov.

Bractea angusta, 3-6 cm longa, 4-8 $\mathrm{mm}$ lata, apice acutiuscula.

Nom. Jap. Arakawa-shinanoki (nov.)

Hab.

Honshū: Arakawa, prov. Ugo (G. KoIE, no. 32, anno 1938-typ:1s in Herb. Tokyo Univ.)

Polygonatum Maximowiczii $F_{R}$. Schmidt var. ramosum Honda var. nov.

Caulis ramosus, ramis floriferis.

Nom. Jap. Edauchi-ōamadokoro (nov.)

Hab.

Hokkaidō: Nishi-shibetsu, prov. Teshio (T. SASAKI, anno 1951-typus in Herb. Tokyo Univ.)

Tragaria nipponica MAKINo form. rosea (NAKAI) Honda comb. nov.

Fragaria nipponica var. rosea NAKAI in sched. Herb. Tokyo Univ.

Petala rosea.

Nom. Jap. Benibana-kusaichigo (T. NAKAI)

Hab.

Honshū: Shizu in Nikkō, prov. shimotsuke (T. NAKAI, anno 1932); in monte Fuji, prov. Suruga (Y. TAKEnAKA, anno 1951) 
Scutellaria iyoensis NAKaI form. albiflora HoNDA form. nov.

Flores albi.

Nom. Jap. Shirobana-hanatatsunamisō (nov.)

Hab.

Shikoku: in monte Saragamine, prov. Iуо (S. YАмАмото, no. 141, anno 1948-typus in Herb. Tokyo Univ.)

Vicia angustifolia LinNAEUs var. segetalis Koch form. albiflora HONDA form. nov. Flores albi.

Nom. Jap. Shirobana-yahazu-endō (nov.)

Hab.

Shikoku: Nanba, prov. Iyo (S. Yамамото, no. 138, anno 1948-typus in Herb. Tokyo Univ.)

Calamagrostis hakonensis Franchet et SAvatier var. glauca Honda var. nov.

Folia subtus (primo supra) glauca.

Nom. Jap. Urajiro-himenogariyasu (nov.)

Hab.

Shikoku : in monte Saragamine, prov. Iyo (S. YамAмото, no. 161, anno 1947-typus in Herb. Tokyo Univ.)

Weigela floribunda K. KOCH form. leucantha HoNDA form. nov.

Flores primo albi demum colorantes.

Nom. Jap. Shirobana-yabu-utsugi (nov.)

Hab.

Shikoku : Sakuragi, prov. Iyo (S. Үамамото, no. 132, anno 1946-typus in Herb. Tokyo Univ.)

Thalictrum Yamamotoi HondA sp. nov.

Caulis erectus, angulatus, glaber, cum inflorescentia usque ad $37 \mathrm{~cm}$ altus. Folia alterna, petiolata, basi amplexicaulia. Stipulae fuscae, membranaceae, margine fimbriatulae, petiolo adnatae. Petioli $1-4 \mathrm{~cm}$ longi, supra sulcati. Lamina ternata; segmenta triternati-pinnata; pinnulae late ovatae, basi rotundatae, apice trilobatae, lobis 2-3-lobatis, $10 \mathrm{~mm}$ longae, 10-15 $\mathrm{mm}$ latae, supra virides, glabrae, minutissime glandulosae, infra glaucae, glabrae, minute glandulosae. Inflorescentia parva, oligantha. Pedicelli gracillimi, 4-5 mm longi. Flores non vidi. Achenia oblonga, 2$2.5 \mathrm{~mm}$ longa, striata, minute glandulosa.

Nom. Jap. Ishizuchi-karamatsu (nov.)

Ḣab.

Shikoku: in monte Ishizuchi, prov. Iуo (S. YАмAMoтo, no. 181, anno 1948-typus in Herb. Tokyo Univ.)

Akin to Thalictrum Thunbergii A.P. DE CANDolle, but distinguishable from this by its dwarf stem, shape of leaflets, and gland-dotted leaves and achenes. 
摘 要

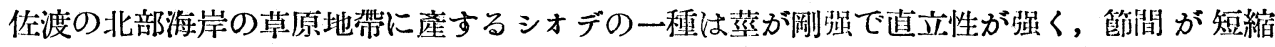
して棐が多い。花は小花梗が短くて密集する觀があり，新種として発表したい。清水大典氏が 昭和 25 年 8 月奥秩父で探集されたベンケイソウの一種はミッバベンライソウに比べて株立ち そなり, 花が正開せず, 秋になると上部の葉腋に然数の肉芽在生する特性があるので,これも新 種として発表する。清水大典氏はその生育地を次の樣に說明して扣られる。「奥秩父山地の西の オグラサン

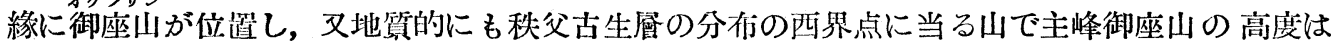
2,112,1 m で，その山暊から東方に向つて秩父三国峠甲武信岳の主稜を形造る彌次平尾根が走つ ており、このベンケィ草の生育地仙この御座山頂から彌次平尾根を約 1 キロばかり東に進んだ 高岩（昭和 25 年の初縱走で新しく命名しけ硅岩の突峰）の崖に著生しているもので，生育点は 岩石ではあるがコメッガの森林に接して比較的濕気が多く, 蘚類のよく有つ処である。そして この生育点の高应は海拔 $1,980 \mathrm{~m}$ 位で，生育する稜線が長野県南佐久郡の南相木村と北相木村 の競界線をなしておる。叉この草の生育量はあまり多くはなく，大体 2 地点 30 株位であるう。」

桑名高校の安井直康氏の採集で, 三重県三重郡三重村にある大池の沿沢地に產し，タテャマ リンドゥの更に小さくなつた一変種と思われるものがある。安井氏によればハルリンドウと混 生し, 現場は標高 $30 \mathrm{~m}$ の低所だそうで西る。サルイワッバキ郎ちユキッバキを最初に調湘に 行つた時の帰途立ち寄つた 若柳村愛宕小学校の校庭で見たケンポナシは潹が小さく，黃金色を 呈し，脈に沿うて僅かに緑が殘つている莧もあるいう変り方であつた。病的のものと思われ

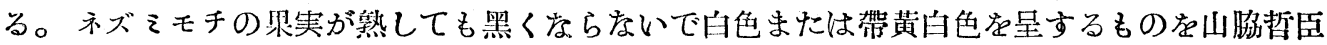
氏が高知市旭の山麓で採集された。ま司氏は愛媛県北宇和郡と南宇和郡との境界に当る由良

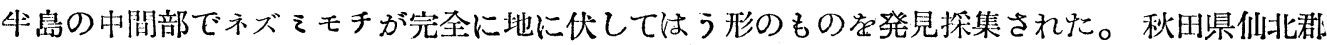
䒪川村で 古家儀八郎氏が採集されたシナノキの一種は苞が塽細で先端が緗く尖つている点が基 準種と違つているので新変種とした。

北海道天塩国士别町西士別で佐々木太一氏が採られたアマドコロ属の一種はオォアマドコ ロと思われるが, 潗腋每に枝をうつて, 更に葉と花とをつけた新しい変種である。シロバナへビ イチゴの花の淡紅色のものを竹中要氏が富士山で探集されたが，これは賏て日光の志津で中井 博士が採られたものと同一品と思われる。愛媛県皿ケ嶺で山本四郎氏の探集されたタッナミン ウの一種はハナタッナそソウの白花品であるから新品種として記載する。

ヤハズエンドゥの白花品も山本四郎氏によつて同県溫泉郡難波村下難波の路傍で探集され た。ヒメノガリヤスの藮裹 (本来の表) が白味を帶びている変種が同氏によつて四ケ嶺で探ら れている。ヤブウッギの白花品が同県周桑郡櫻樹村にあり，これも山本四郎氏によつて探集さ れた。石桘山酉冠岳で同氏の探集されたカラマッッウ属の一種はアキカラマッの高い山に上つ た形とも見られるが, 高さが低く、小葉の形に異点が認められ，葉の表裏ならびに果実に 細かい 腺点が見られるので别種と考えた。

最後に本論文は文部省科学研究費の一部でなされたこと教して感謝の意を表す。 